\title{
GROWTH ESTIMATION AND LENGTH-WEIGHT RELATIONSHIPS OF SPOTTAIL MANTIS SHRIMP (SQUILLA MANTIS, LINNEAUS 1758) IN THE ALGIERS REGION (SOUTH- WEST OF MEDITERRANEAN SEA)
}

\author{
KENNOUCHE, H. $^{1 *}-$ KACIMI, A. ${ }^{2}$ \\ ${ }^{1}$ Management and enhancement of agricultural and aquatic ecosystems laboratory, Institute of \\ Sciences, Morsli Abdellah University Center, 42000 Tipaza, Algeria \\ (phone: +213-2437-1003; fax: +213-2437-1006) \\ ${ }^{2}$ Marine and Coastal Ecosystems Laboratory (ECOSYSMarL), National Higher School of \\ Marine Sciences and Coastal Management (ENSSMAL), 16320 Algiers, Algeria \\ (phone: +213-2191-7743; fax: +213-2191-7791) \\ "Corresponding author \\ e-mail: kennouchehanane@yahoo.fr \\ (Received $5^{\text {th }}$ Aug 2021; accepted $1^{\text {st }}$ Oct 2021)
}

\begin{abstract}
This study concerns the growth and biometric relations of the mantis shrimp Squilla mantis from the region of Algiers. A total of 1064 individuals were sampled from the trawl fishery landings, between December 2016 and December 2017. The results show the different growth parameters, established on cephalothorax measurements $\left(L c_{\infty}=48.06 \mathrm{~mm} ; K=0.34 \mathrm{yr}^{-1} ; t_{0}=-0.69\right.$ year $)$ and total length values $\left(L t_{\infty}=189.9 \mathrm{~mm} ; K=0.48 \mathrm{yr}^{-1} ; t_{0}=-0.66\right.$ year). The decomposition of size structures according to the Bhattacharya method yielded four age classes based on the cephalothorax and total length $\left(0^{+}-3\right)$. The total mortality $(Z)$ calculated from Ricker curve was 1.32 year $^{-1}$, and the natural mortality coefficient $M$ was calculated at 0.95 year $^{-1}$ indicating an under-exploitation of the S. mantis stock in this area. Different biometric relationships are established of the size-size and size weight type highlighting an allometry coefficient higher than 1 and lower than 3, respectively for the size-size and size-weight relationships, translating a major growth of the total size and a minor growth of the weight. Researchers and decision makers can integrate these results in analytical, bioenergetic and bioeconomic models to better manage the exploitation of the S. mantis stock in the western Mediterranean basin.
\end{abstract}

Keywords: S. mantis mortality, population dynamic, age structure, biometric relationship, Algeria, Mediterranean-Western basin

\section{Introduction}

Of the nine species of Mediterranean Stomatopods, only the spottail mantis shrimp, Squilla mantis, is of appreciable economic importance (Maynou et al., 2004). Its range extends from Angola to the Gulf of Cadiz (Manning, 1977). In the Atlantic, this species seems to be present only in the Gulf of Cadiz (Maynou et al., 2004), while in the Mediterranean, it is reported in Egypt, Syria, Greece, Turkey, Italy, France, Spain, Palestine, Algeria (Schram and Muller, 2004) and on the Tunisian coast (Mili et al., 2011). It is found at sublittoral depths greater than $3 \mathrm{~m}$ on sandy and muddy bottoms up to $200 \mathrm{~m}$ deep, but generally at less than $50 \mathrm{~m}$ (Holthuis, 1987). Its presence is reported on the entire Algerian coast, and studies carried out in the Algerian basin have highlighted its relatively high abundance in the center of the basin, in particular, in the bay of Bou Ismail between 50 and $100 \mathrm{~m} . S$ mantis prefers compact and sandy liquid muds and fine sand, and average temperatures of 13.2 to $15.3^{\circ} \mathrm{C}$ (Campilo, 1982). Its 
catch on the Algerian coast in the last five years has recorded a maximum landing rate of $3232.9 \mathrm{Kg}$ in 2016 (Fig. 1; Ministry of Fisheries and Fisheries Production, 2021).

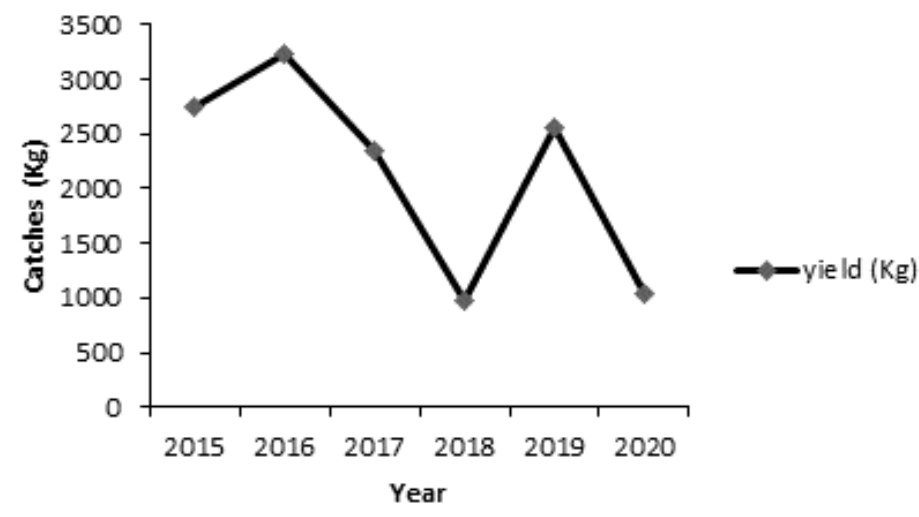

Figure 1. Catch of S. mantis in Algeria between 2015 and 2020 (Ministry of Fisheries and Fisheries Production, 2021)

S. mantis has been the subject of numerous research studies in the Mediterranean and Atlantic. Among these works, we mention those of Ragonese et al. (2012) in the southern coast of Sicily, Vasconcelos et al. (2017) in algarve coast, Erdogan-Saglam et al. (2017) in the bay of Izmir, Vila et al. (2013) in the Gulf of Cadiz, Kampouris et al. (2018) in the Thermaikos Gulf, Veneroni and Fernandes (2021) in the northern Adriatic sea; Mili et al. $(2008,2013,2014)$ in Tunisia; but no study has been undertaken on this species in Algeria.

S. mantis is caught in limited quantities and essentially on trawlable bottoms by means of demersal trawls. In the past, this species was considered as a fishing product of low market value not appreciated by Algerians for lack of culinary tradition and was consequently rejected at sea after its capture. But given the high price of wild shrimp in recent years, this species has begun to attract interest by the Algerian consumer (Fig. 1). Indeed, $S$. mantis has become popular in fish shops in the central region with prices $/ \mathrm{kg}$ ranging between 400 and 500 Algerian dinars at retail (about 3 euros). Compared to the numerous investigations undertaken on Peneidae (Derbal and Soltani, 2008; Kennouche, 2009), Aristeidae (Mouffok et al., 2005, 2008; Nouar and Kennouche, 2013) or Pandalidae (Derbal and Kara, 2006) from the Algerian coasts, Stomatopods have not attracted the same scientific interest. Moreover, there is no comprehensive information on the biology, ecology or exploitation level of Stomatopods in Algeria. In order to better understand the available stocks of Stomatopods along the Algerian coasts, this study aims to provide new data on the growth and biometric relationships of $S$. mantis in the Algerian region in a perspective of rational exploitation and valorization of this carcinological resource.

\section{Material and methods}

\section{Sampling}

Between December 2016 and December 2017, 1064 individuals of S. mantis were sampled from the landings of the commercial trawl fishery conducted in the Algiers region (Fig. 2). 


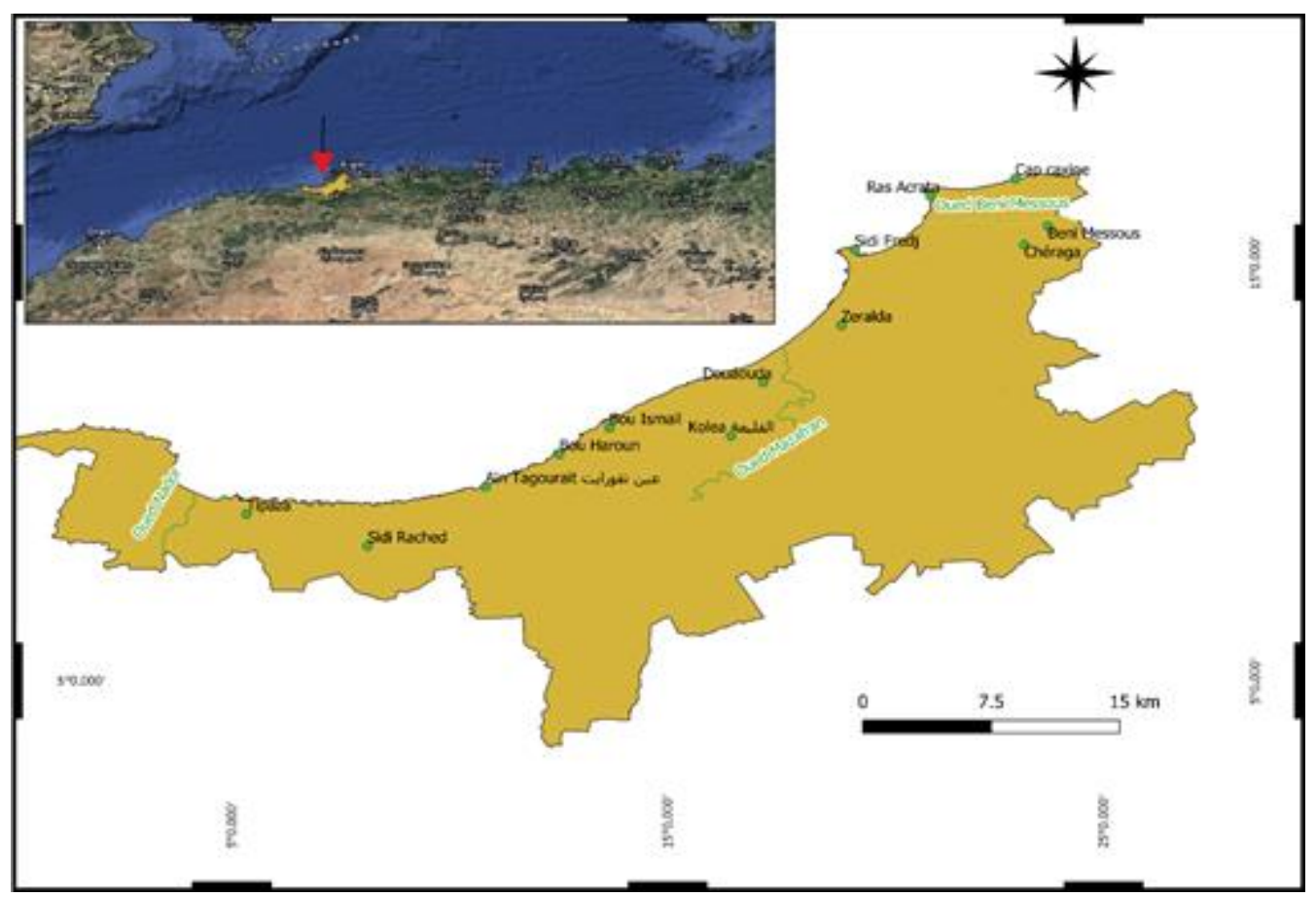

Figure 2. Map of the study area in the central region of the Algerian basin

Measurements were made on each individual using an ichthyometer, for the measurement of total length $(\mathrm{Lt})$ and telson $(\mathrm{Ltel})$, and a caliper, for the measurement of cephalothoracic length $(L c)$. Total weight $(W t)$ was determined with a $0.01 \mathrm{~g}$ precision scale (Fig. 3). The sex of S. mantis is easily identified by the presence of a pair of copulatory organs from the base of the third pair of pereiopods corresponding to the 8th thoracic segment in males and by the presence of the genital plate on the sternite of the $6^{\text {th }}$ thoracic segment in females (Abelló and Martín, 1993). Also, other individuals (152 specimens) were measured and considered without distinction of sex, because of the deterioration of some frozen individuals.

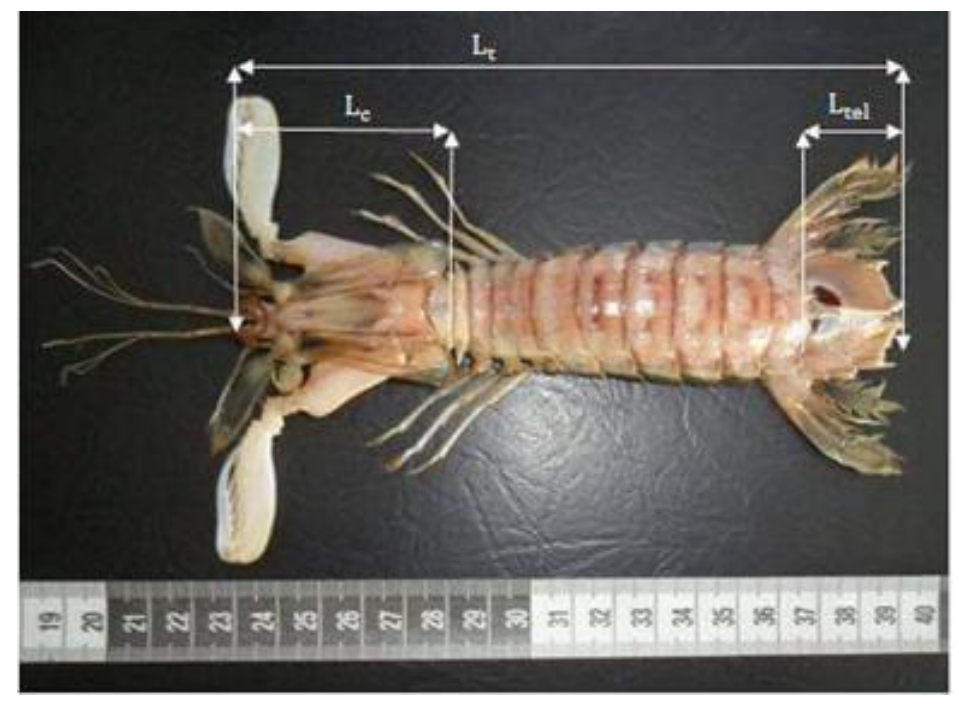

Figure 3. The different measurements made on S. mantis 


\section{Age and growth}

The age of the specimens was determined from length-frequency data analysis using Bhattacharya's method in the FISAT II software. This method, which is based on logarithmic differences, was outlined by Bhattacharya (1967), taken up by Masson (1970) and applied by Gayanilo et al. (2002). The growth in length of this species has been described using the Von Bertalanffy equation (Ricker, 1975; Beverton and Holt, 2012; Eq. 1):

$$
\mathrm{Lt}=L \infty\left(1-e^{-K(t-t 0)}\right)
$$

with: Lt: total length at age $\mathrm{t}(\mathrm{cm}), \mathrm{L} \infty$ : asymptotic length $(\mathrm{cm}), \mathrm{K}$ : growth coefficient $\left(\mathrm{yr}^{-1}\right), \mathrm{t}$ : age $(\mathrm{yr}), \mathrm{t} 0$ : the hypothetical age corresponding to zero theoretical length (Sparre and Venema, 1992; King, 2013). The Von Bertalanffy exponential growth models were evaluated using the root mean square error (RMSE). The RMSE gives an overview of the overall difference between the predicted (VBGE) and observed (Bhattacharya decomposition) values.

The length performance ( $\left.\varnothing^{\prime}\right)$ was estimated using the equation $(E q .2)$, given by Moreau et al. (1986):

$$
\emptyset^{\prime}=\log K+2 \log L \infty
$$

The asymptotic length $L_{\infty}$ was estimated from the size frequency distribution by the method of Powell (1979); Wetherall (1986) using the FISAT II software, version 1.2.0 (Gayanilo et al., 2002). This same software also allowed us to estimate the growth rate $K$ by analyzing the age-length key obtained by Bhattacharya (1967) multimodal decomposition. The analysis of this age-length key was performed according to the iterative method of Tomlinson and Abramson (1961), a method based on a "least square" type of adjustment by integrating the $L_{\infty}$ obtained by Powell (1979) and Wetherall (1986). This method estimates the parameter $K$ so that the sum of the squares of the differences between the model and the observations is minimal (Gayanilo et al., 2002).

The age at time "zero", represented by to is calculated by Pauly (1980) (Eq. 3):

$$
\log 10(\mathrm{t} 0)=-0.3922-0.2752 \log 10 L_{\infty}-1.038 \log 10 \mathrm{~K}
$$

\section{Biometric relations}

For the biometric study of the mantis shrimp, we established the following morphometric relationships: Ltel $=F(L c), L t=F($ Ltel $), L t=F(L c), W t=F(L c)$, $W t=F(L t e l)$ and $W t=F(L t)$. With: Ltel: telson length, Lc: cephalothoracic length, $L t$ : total length and $W t$ : total weight. These relationships were expressed by a linear model of the form $\mathrm{y}=\mathrm{a} \mathrm{x}+\mathrm{b}$ for length-length relationships and $\log \mathrm{w}=\log \mathrm{a}+\mathrm{b} \log \mathrm{L}$ for length-weight relationships. Where $W=$ total weight, $L=L t, L c$, or Ltel, $a=$ intercept and $b=$ slope of the regression line for length-weight relationships, these parameters are inverted for length-length relationships ( $a$ : slope of the regression line and $b$ : intercept). The exponent $b$ is the allometry coefficient reflecting the proportionality of the growth of a given trait to the reference trait $(b<3$ negative 
allometry, $b=3$ isometry, $b>3$ positive allometry). For length-length relationships, the slope coefficient $a$ reflects the nature of the allometry ( $a<1$ minor allometry, $a>1$ major allometry, $a=1$ isometry).

In addition, $t$-test for slope conformity was performed to confirm the type of allometry for the length-weight and length-length relationships (Eqs. 4,5) for the sizeweight relationships and length-length relationships, respectively:

$$
\begin{aligned}
& t=\frac{[(b-3)]}{s d(b)} \\
& t=\frac{[(b-1)]}{s d(b)}
\end{aligned}
$$

with:

$$
s d(b)=\sqrt{\frac{\delta y^{2}}{\frac{\delta x^{2}}{n-2}\left(1-R^{2}\right)}}
$$

with $\delta y^{2}$ : Variance of variable $y, \delta x^{2}$ : variance of variable $\mathrm{x}, R^{2}$ : coefficient of determination, $n-2$ : degree of freedom and $\alpha=0.05$. If $t<1.96$ non-significant difference, if $t>1.96$ significant difference. In addition, statistical analyses were performed to test the significance of the difference between the calculated and observed values. Differences in sex ratios, based on a theoretical ratio of $1: 1$, were assessed using Chi-square $\left(\chi^{2}\right)$ analysis in $\mathrm{R}$ (4.0.3). Sample normality was tested by the Kolmogorov Smirnov test and homogeneity of variances with the Levene test using STATISTICA 6.1. ANOVA of the regression models (length-weight and length-length) was used to test the significance of the latter ( $\mathrm{R}$ 4.0.3).

\section{Mortality}

The instantaneous coefficient of total mortality $(Z)$ was calculated by the capture curve given by Ricker (1975); where $Z$ is equal to the slope of the descending part of the curve. Natural mortality $(M)$ was estimated using the empirical equation of Pauly (1983) (Eq. 7):

$$
\log M=-0.0066-0.279 \log L \infty+0,6543 \log K+\log T^{\circ}
$$

with $T^{\circ}$ : temperature of the seawater $\left({ }^{\circ} \mathrm{C}\right)$. The mortality coefficient $(F)$ was deduced from the formula $F=Z-M$ (Gulland, 1971). The exploitation rate $(E)$ was estimated according to the ratio: $E=F / Z$ (Gulland, 1971). All statistical analyses were conducted using STATISTICA 6.1, R 4.0.3 and Microsoft Excel® software.

\section{Results}

\section{Statistical analysis}

The mean total length $(L t)$, cephalothoracic length $(L c)$, telson length (Ltel), and mean weight of 1064 Squilla mantis specimens were $13.39 \pm 0.16(\mathrm{~cm}), 2.99 \pm 0.04(\mathrm{~cm})$, $2.35 \pm 0.03(\mathrm{~cm})$, and $29.18 \pm 0.99(\mathrm{~g})$, respectively (Table 1). Males were slightly larger 
than females, but the difference was statistically insignificant $(P>0.05)$. The sex ratio was $52.82 \%$ for females versus $47.18 \%$ for males. Chi-square analyses show that the difference between males $(47.18 \%)$ and females $(52.82 \%)$ is not statistically significant (Table 2). Males and females were equally represented in the western Mediterranean population of $S$. mantis.

Table 1. Sex, mean total length $(\mathrm{cm})$, carapace length $(\mathrm{cm})$ and weight $(\mathrm{g})$ of Squilla mantis from the Mediterranean Sea-Western Basin

\begin{tabular}{c|c|c|c|c}
\hline Sex & $\begin{array}{c}\text { Total length }(\mathbf{c m}) \\
(\mathbf{m i n}-\mathbf{m a x})\end{array}$ & $\begin{array}{c}\text { Carapace length } \\
\text { (cm) }(\mathbf{m i n}-\mathbf{m a x})\end{array}$ & $\begin{array}{c}\text { Telson length }(\mathbf{c m}) \\
(\mathbf{m i n}-\mathbf{m a x})\end{array}$ & $\begin{array}{c}\text { Weigth } \mathbf{( g )} \\
(\mathbf{m i n}-\mathbf{m a x})\end{array}$ \\
\hline $\mathrm{Male}$ & $13.71 \pm 0.24$ & $3.26 \pm 0.0 .6$ & $2.42 \pm 0.05$ & $31.56 \pm 1.57$ \\
$\mathrm{~N}=422$ & $(9.5-17.3)$ & $(2.35-4.15)$ & $(1.6-3.1)$ & $(8.88-61.56)$ \\
\hline Female & $13.28 \pm 0.2$ & $3.08 \pm 0.05$ & $2.30 \pm 0.04$ & $26.98 \pm 1.16$ \\
$\mathrm{~N}=490$ & $(9.5-16.3)$ & $(2.25-3.8)$ & $(1.6-2.9)$ & $(9.68-50.5)$ \\
\hline Total & $13.39 \pm 0.16$ & $2.99 \pm 0.04$ & $2.35 \pm 0.03$ & $29.18 \pm 0.99$ \\
$\mathrm{~N}=1064$ & $(6-18.5)$ & $(2.35-4.5)$ & $(1.6-3.1)$ & $(8.88-61.56)$ \\
\hline
\end{tabular}

Table 2. Statistical tests applied on the different measurements of S.mantis

\begin{tabular}{|c|c|c|c|c|}
\hline $\begin{array}{l}\text { Male vs } \\
\text { Female }\end{array}$ & $\begin{array}{l}\text { Total length } \\
\text { (cm) }\end{array}$ & $\begin{array}{c}\text { Carapace length } \\
\text { (cm) }\end{array}$ & $\begin{array}{l}\text { Telson length } \\
\text { (cm) }\end{array}$ & $\begin{array}{l}\text { Weigth } \\
\text { (g) }\end{array}$ \\
\hline $\begin{array}{l}\text { Levene's Test } \\
\text { for Equality of } \\
\text { Variances } \\
\end{array}$ & $P=0.37$ & $P=0.01$ & $P=0.013$ & $P=0.02$ \\
\hline $\begin{array}{c}t \text { test for } \\
\text { independent } \\
\text { samples }\end{array}$ & $P=0.0052$ & $P=10^{-6}$ & $P=6.3 \times 10^{-5}$ & $P=3 \times 10^{-6}$ \\
\hline $\begin{array}{c}\text { Kolmogorov- } \\
\text { Smirnov } \\
\text { normality test }\end{array}$ & $\begin{array}{c}\mathrm{P}_{\text {male }}=0.119 \\
\mathrm{P}_{\text {female }}=0.087\end{array}$ & $\begin{array}{c}\mathrm{P}_{\text {male }}=0.1 \\
\mathrm{P}_{\text {female }}=0.092\end{array}$ & $\begin{array}{c}\mathrm{P}_{\text {male }}=0.113 \\
\mathrm{P}_{\text {female }}=0.089\end{array}$ & $\begin{array}{l}P_{\text {male }}=0.052 \\
P_{\text {female }}=0.06\end{array}$ \\
\hline $\begin{array}{l}\text { Chi-squared } \\
\text { test for sex } \\
\text { ratio }(F / M)\end{array}$ & \multicolumn{4}{|c|}{$P=0.07$} \\
\hline
\end{tabular}

Significant difference marked at $P<0.05$. For the Kolmogorov-Smirnov test, the normality of the distribution is accepted at $P>0.05$

Levene's test of homogeneity of variances, applied between males and females indicates a non-significant difference for total length. However, this same test asserts a heterogeneity of variances for cephalothoracic length, telson length and weight (Table 2). The Kolmogorov-Smirnov normality test shows that the different distributions of size and weight follow a normal distribution. The $t$-test for independent samples shows a significant difference in the growth of male and female $S$. mantis (Table 2), which suggests a sex-dependent growth study.

\section{Linear growth estimation}

Figure 4 shows the frequency-size distributions of the sample. The decomposition of these distributions with Bhattacharya's logarithmic difference method, revealed four age groups of $0^{+}-3$ years for the different measurements Lt, Lc, Ltel (Fig. 4 and Fig. 5). 

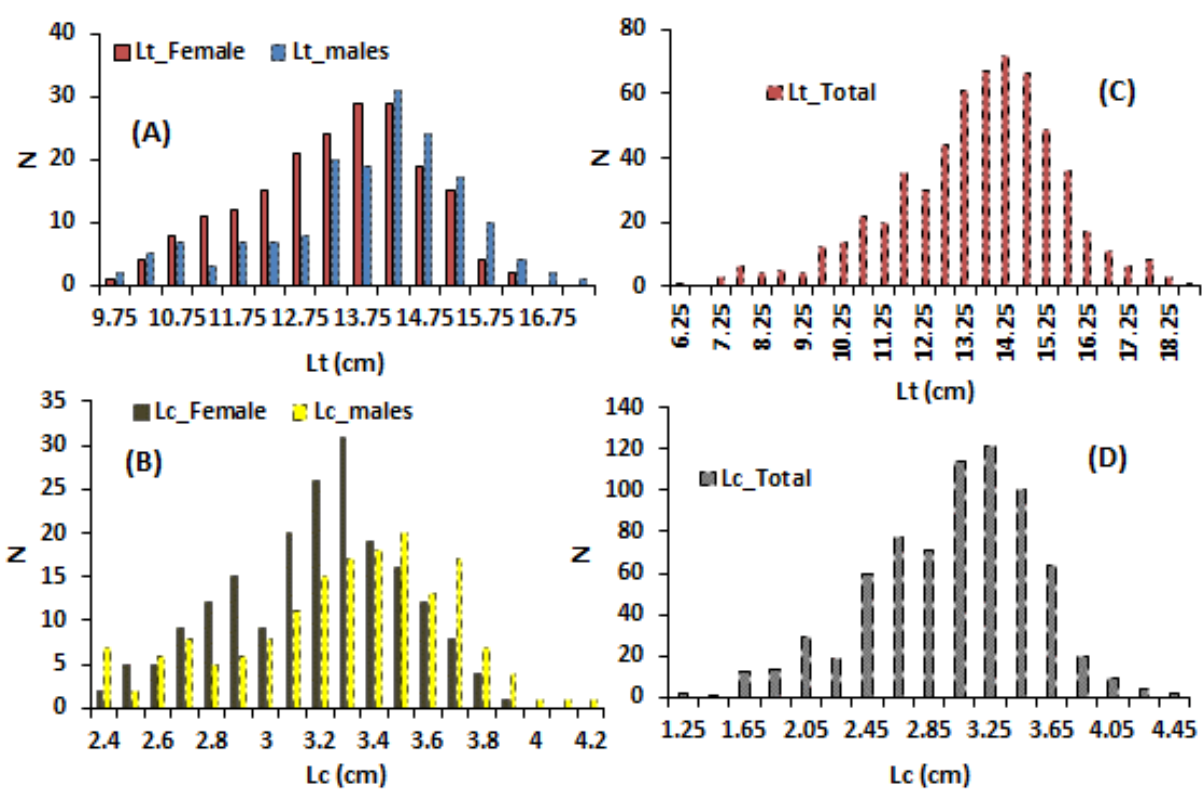

Figure 4. Length frequency distribution for males and females of $S$. mantis, $(A)$ : Total length for male and female, $(B)$ : Carapace length for male and female, $(C)$ : Total length for both sex, $(D)$ : Carapace length for both sex
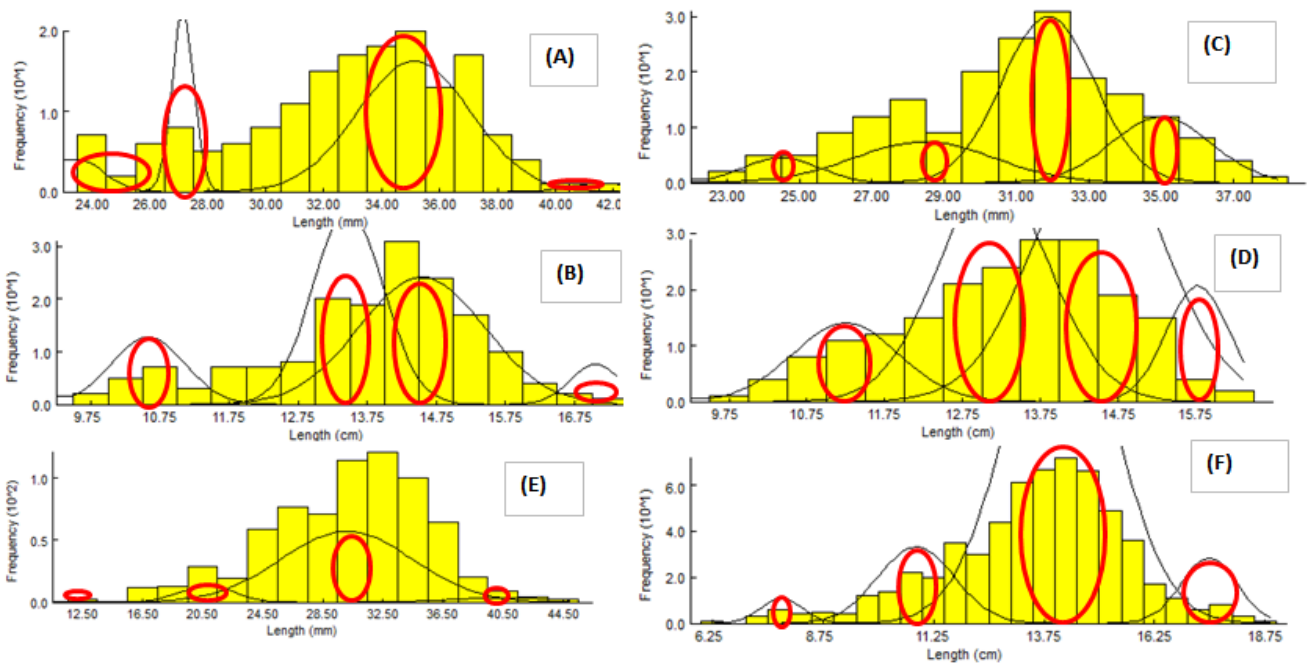

Figure 5. Decomposition of length frequency structures by the Bhattacharya's method in FISAT II. (A): Carapace length for male. (B): Total length for male. $(C)$ : Carapace length for females. (D): Total length for females. $(E)$ : Carapace length for both sex. $(F)$ : Total length for both sex. The red circles represent the age groups

These results indicate that $S$. mantis can be considered a fast growing species. The fastest growth occurs mostly in the age interval $0-1$.

Bhattacharya's method consists of separating normal components, each representing a cohort of S. mantis, from the overall distribution, starting from a left side (Fig. 4). Fig. 5 shows different multimodal distributions with several peaks that can be divided 
into four subsamples. These distributions result from a length frequency table with a step of $0.1 \mathrm{~cm}$ for cephalothoracic lengths and $0.5 \mathrm{~cm}$ for total lengths.

For mean male sizes of $13.71 \pm 0.24,3.26 \pm 0.06$ and for mean female sizes of $13.28 \pm 0.2,3.08 \pm 0.05$; the method of Powell (1979); Wetherall (1986) allowed to estimate asymptotic lengths for males and females: $18.25 \mathrm{~cm}, 39.40 \mathrm{~mm}, 18.56 \mathrm{~cm}$, $42.50 \mathrm{~cm}$, respectively for total and cephalothorax lengths. The calculated asymptotic lengths are consistent with the differences in growth observed between males and females of $S$. mantis in the Algerian region, i.e. males show a slightly faster growth than females in this bay (Table 3). The coefficients of catabolism $K$ estimated from total and cephalothorax length are very close to each other, with a slight difference in favor of females, and a slight underestimation when sex is taken together. Calculation of the performance index $\emptyset^{\prime}$ gives an overall view on the rapid growth of $S$. mantis (2.36-3.06); highly similar for both sexes (Table 3). The growth equations as a function of $L t$ and $L c$ are: $L t=18.25\left(1-e^{-0.69(t+0.56)}\right), L c=39.40\left(1-e^{-0.71(t+0.51)}\right)$ for females $L t=18.56\left(1-e^{-0.67(t+0.57)}\right), L c=45.50\left(1-e^{-0.64(t+0.53)}\right)$ for males, Lt $=18.99\left(1-e^{-0.48(t+0.66)}\right), \quad \mathrm{Lc}=48.06\left(1-e^{-0.34(t+0.69)}\right) \quad$ for all sexes combined.

Table 3. Growth parameters obtained for the mantis shrimp S. mantis from the western Mediterranean basin

\begin{tabular}{c|c|c|c|c|c}
\hline Sex & $\begin{array}{c}\text { Length } \\
\text { measurements } \\
(\mathbf{c m})\end{array}$ & $\begin{array}{c}\mathbf{L}_{\infty} \\
\text { (Powell, 1979; } \\
\text { Wetherall, 1986) }\end{array}$ & $\begin{array}{c}\text { K (year-1) } \\
\text { (Tomlinson and } \\
\text { Abramson, 1961) }\end{array}$ & $\begin{array}{c}\mathbf{t}_{0} \\
\text { (Pauly, 1980) }\end{array}$ & $\emptyset^{\prime}$ \\
\hline Male & Lt (cm) & 18.25 & 0.69 & -0.56 & 2.36 \\
N=422 & Lc (mm) & 39.40 & 0.71 & -0.51 & 3.04 \\
\hline Female & Lt (cm) & 18.56 & 0.67 & -0.57 & 2.36 \\
N=490 & Lc (mm) & 42.50 & 0.64 & -0.53 & 3.06 \\
\hline Total & Lt (cm) & 18.99 & 0.48 & -0.66 & 2.24 \\
N=1064 & Lc (mm) & 48.06 & 0.34 & -0.69 & 2.9 \\
\hline
\end{tabular}

The age-length key developed for the mantis shrimp $S$. mantis highlighted age groups ranging from $0^{+}$to 3 regardless of the length used ( $L t$ or $L c$ ) (Table 4). Bhattacharya's multimodal decomposition led to mean lengths of $13.91 \mathrm{~cm}, 31.88 \mathrm{~mm}$ for males and $13.67 \mathrm{~cm}, 29.96 \mathrm{~mm}$ for females; $12.57 \mathrm{~cm}, 25.76 \mathrm{~mm}$ for all sexes combined; which is very close to the means actually sampled in the population.

RMSE values are expressed as the percentage of the mean observed in each sampled length to give more meaning to this statistical estimator. For males, the overall variance of the Von Bertalanffy model was $17.77 \%$ for "total length" and $18.70 \%$ based on "cephalothorax length"; this means that the two growth models estimated for males explained $82.23 \%, 81.3 \%$ of the observations. The RMSE for females was $20.57 \%$, $21.47 \%$, based on "total" and "cephalothorax length". For all sexes combined, the growth model developed performed well, explaining $87.06 \%, 87.29 \%$ of the average observations. The calculated growth rate indicates rapid growth during early stages, followed by slower growth as the species approaches $L_{\infty}$. The two growth rates estimated for Bhattacharya's age-length key and from Von Bertalanffy's growth equation (Eq.1), show a divergence for the early age groups, suggesting that the size range is not fully sampled due to gear selectivity. 
Table 4. Age-length key, growth rate, root mean square error obtained for the mantis-shrimp S. mantis from the central Algerian region

\begin{tabular}{|c|c|c|c|c|c|c|c|}
\hline Sex & $\begin{array}{c}\text { Measurement } \\
(\mathrm{cm})\end{array}$ & Age group & Bhattacharya & VBGE & RMSE & $\begin{array}{c}\text { RMSE/MEAN } \\
(\%)\end{array}$ & $\begin{array}{c}\text { Growth rate } \\
\text { (Bhattacharya- } \\
\text { VBGE) }\end{array}$ \\
\hline \multirow{10}{*}{ Male } & \multirow{4}{*}{$\mathrm{Lt}(\mathrm{cm})$} & 0 & 10.58 & 5.89 & \multirow{4}{*}{2.47} & \multirow{4}{*}{17.77} & \\
\hline & & 1 & 13.47 & 12.08 & & & $2.89 / 6.19$ \\
\hline & & 2 & 14.54 & 15.24 & & & $1.07 / 3.17$ \\
\hline & & 3 & 17.05 & 16.86 & & & $2.51 / 1.62$ \\
\hline & \multirow[t]{2}{*}{ Mean } & & 13.91 & & \multirow{6}{*}{5.96} & \multirow{6}{*}{18.70} & \\
\hline & & 0 & 23.5 & 12.23 & & & \\
\hline & \multirow{3}{*}{$\mathrm{Lc}(\mathrm{mm})$} & 1 & 27.14 & 26.54 & & & $3.64 / 14.31$ \\
\hline & & 2 & 35.13 & 34.08 & & & $7.99 / 7.55$ \\
\hline & & 3 & 41.75 & 38.06 & & & $6.62 / 3.9$ \\
\hline & Mean & & & & & & \\
\hline \multirow{10}{*}{ Female } & \multirow{4}{*}{$\mathrm{Lt}(\mathrm{cm})$} & 0 & 11.25 & 5.85 & \multirow{4}{*}{2.81} & \multirow{4}{*}{20.57} & \\
\hline & & 1 & 13.15 & 12.03 & & & $1.9 / 6.18$ \\
\hline & & 2 & 14.51 & 15.13 & & & $1.36 / 3.10$ \\
\hline & & 3 & 15.78 & 16.69 & & & $1.27 / 1.55$ \\
\hline & \multirow[t]{2}{*}{ Mean } & & 13.6725 & & \multirow{6}{*}{6.43} & \multirow{6}{*}{21.47} & \\
\hline & & 0 & 24.5 & 11.97 & & & \\
\hline & \multirow{3}{*}{$\mathrm{Lc}(\mathrm{mm})$} & 1 & 28.45 & 25.91 & & & $3.95 / 13.94$ \\
\hline & & 2 & 31.88 & 32.77 & & & $3.43 / 6.86$ \\
\hline & & 3 & 35 & 36.14 & & & $3.12 / 3.37$ \\
\hline & Mean & & 29.9575 & & & & \\
\hline \multirow{10}{*}{ Combined } & \multirow{4}{*}{$\mathrm{Lt}(\mathrm{cm})$} & 0 & 7.82 & 5.16 & \multirow{4}{*}{1.63} & \multirow{4}{*}{12.94} & \\
\hline & & 1 & 10.86 & 10.43 & & & $3.04 / 5.27$ \\
\hline & & 2 & 14.12 & 13.69 & & & $3.26 / 3.26$ \\
\hline & & 3 & 17.48 & 15.71 & & & $3.36 / 2.02$ \\
\hline & \multirow[t]{2}{*}{ Mean } & & 12.57 & & \multirow{6}{*}{3.27} & \multirow{6}{*}{12.71} & \\
\hline & & 0 & 11.5 & 10.05 & & & \\
\hline & \multirow{3}{*}{$\mathrm{Lc}(\mathrm{mm})$} & 1 & 20.81 & 21.01 & & & $9.31 / 10.96$ \\
\hline & & 2 & 30.11 & 28.80 & & & $9.3 / 7.80$ \\
\hline & & 3 & 40.6 & 34.35 & & & $10.49 / 5.55$ \\
\hline & Mean & & 25.755 & & & & \\
\hline
\end{tabular}

\section{Biometric relations}

From the different measurements, linear relationships were established of the "length-length" and "length-weight" type. Tables 5 and 6 summarize the equations, the correlation coefficients linking the "length-length" and "length-weight" measurements as well as the different results of the statistical tests applied to each model. These models were obtained using the least squares method which consists of determining the parameters of the intercept and the slope of the regression line so that the sum of the squares of the residual errors is as small as possible. 
Table 5. Length-length relationship parameters obtained for the mantis-shrimp S.mantis from the Algiers region $(R$ 4.0.3)

\begin{tabular}{|c|c|c|c|c|c|c|c|c|}
\hline $\begin{array}{c}\text { Biometric } \\
\text { relation }\end{array}$ & Sex & $\mathbf{a}$ & b & \begin{tabular}{|l}
$\begin{array}{l}\text { Std.Error } \\
\text { (a and b) }\end{array}$ \\
\end{tabular} & t value & $\operatorname{Pr}(>|t|)$ & $\mathbf{R}^{2}$ & $\begin{array}{c}\text { F- } \\
\text { Statistic } \\
\end{array}$ \\
\hline \multirow{6}{*}{ Ltel $=a \times$ Lc $+b$} & \multirow{2}{*}{ Female } & $\begin{array}{c}0.668 \\
(0.608-\end{array}$ & $0.24(0.058-$ & 0.03 & 21.96 & $<2 \times 10^{-16 * * *}$ & \multirow{2}{*}{0.715} & \multirow{2}{*}{482.1} \\
\hline & & $0.729)$ & & 0.09 & 2.59 & $0.0102 *$ & & \\
\hline & \multirow{2}{*}{ Male } & $\begin{array}{c}0.6716 \\
(0.61-\end{array}$ & $0.23(0.023-$ & 0.032 & 21.070 & $<2 \times 10^{-16 * * *}$ & \multirow{2}{*}{0.729} & \multirow{2}{*}{444} \\
\hline & & $0.735)$ & 0.437) & 0.105 & 2.194 & 0.0296 & & \\
\hline & \multirow{2}{*}{ Total } & $\begin{array}{r}0.669 \\
0627-\end{array}$ & 0.244 (0.11- & 0.02118 & 31.550 & $<2 \times 10^{-16 * * *}$ & \multirow{2}{*}{0.735} & \multirow{2}{*}{995.4} \\
\hline & & $\begin{array}{c}(0.02 /- \\
0.71)\end{array}$ & $0.38)$ & 0.06747 & 3.611 & $3.49 \times 10-4 * * *$ & & \\
\hline \multirow{6}{*}{$\mathrm{Lt}=\mathrm{a} \times \mathrm{Ltel}+\mathrm{b}$} & \multirow{2}{*}{ Female } & $\begin{array}{l}4.4774 \\
(4.045-\end{array}$ & $\begin{array}{l}2.9731 \\
(1.971-\end{array}$ & 0.2193 & 20.417 & $<2 \times 10^{-16 * * *}$ & \multirow{2}{*}{0.684} & \multirow{2}{*}{416.9} \\
\hline & & $4.91)$ & $3.974)$ & 0.5079 & 5.845 & $2.05 \times 10^{-8 * * * *}$ & & \\
\hline & \multirow{2}{*}{ Male } & $\begin{array}{r}4.33 \\
3.05\end{array}$ & $3.22(2.29-$ & 0.1928 & 22.471 & $<2 \times 10^{-16 * * *}$ & \multirow{2}{*}{0.754} & \multirow{2}{*}{504.9} \\
\hline & & $\begin{array}{l}(3.95- \\
4.71)\end{array}$ & 4.15) & 0.4709 & 6.831 & $1.54 \times 10^{-10} * * *$ & & \\
\hline & \multirow{2}{*}{ Total } & 4.36 & 3.19 (2.54- & 0.1416 & 30.796 & $<2 \times 10^{-16 * * *}$ & \multirow{2}{*}{0.73} & \multirow{2}{*}{948.4} \\
\hline & & $\begin{array}{l}(4.08- \\
4.64)\end{array}$ & 3.86) & 0.3364 & 9.506 & $<2 \times 10^{-16 * * *}$ & & \\
\hline \multirow{6}{*}{$\mathrm{Lt}=\mathrm{a} \times \mathrm{Lc}+\mathrm{b}$} & \multirow{2}{*}{ Female } & 3.7953 & $1.60(0.73-$ & 0.1428 & 26.573 & $<2 \times 10^{-16 * * *}$ & \multirow{2}{*}{0.786} & \multirow{2}{*}{706.1} \\
\hline & & $4.077)$ & & 0.4417 & 3.637 & $3.5 \times 10^{-4} * * *$ & & \\
\hline & \multirow{2}{*}{ Male } & $\begin{array}{r}3.46 \\
3.18\end{array}$ & $2.40(1.47-$ & 0.1438 & 24.083 & $<2 \times 10^{-16 * * *}$ & \multirow{2}{*}{0.779} & \multirow{2}{*}{580} \\
\hline & & $3.75)$ & 3.34) & 0.4729 & 5.087 & $9.8 \times 10^{-7} * * *$ & & \\
\hline & \multirow{2}{*}{ Total } & $\begin{array}{l}3.78 \\
3.63\end{array}$ & 1.70 (1.26- & 0.07226 & 52.241 & $<2 \times 10^{-16 * * *}$ & \multirow{2}{*}{0.82} & \multirow{2}{*}{2729} \\
\hline & & $3.92)$ & & 0.22649 & 7.519 & $2.05 \times 10^{-13} * * *$ & & \\
\hline
\end{tabular}

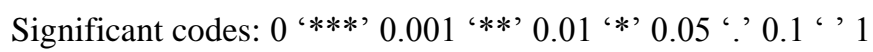

The linear biometric relationships (Table 5) show a majoring allometry $(a>1)$ for the relationships $L t=a \times L t e l+b, L t=a \times L c+b$ and a minoring allometry for relationships of the type Ltel $=a \times L c+b(a<1)$. The $F$-test based on Fisher's statistic shows a very high overall significance of all models $\left(P_{-}\right.$value $<2 \times 10^{-16}$ and $\left.416.9 \leq F \leq 2729\right)$. Student's $t$ test applied on the regression coefficients $a$ and $b$ (Table 5) indicates a high significance of the slope coefficients $a\left(\operatorname{Pr}(>|t|)<2 \times 10^{-16}\right)$, which is significant at the error rate $\alpha=0.001$. The values of the intercept coefficients $b$ are highly significant for all models $\left(2 \times 10^{-16} \leq \operatorname{Pr} \leq 0.0102\right)$, except for the model $L t=a \times L c+b$ established for males $(\mathrm{Pr}=0.0296)$ (Table 5). The Standard error ranged from 0.03-0.4729, which led to confidence intervals between 0.608-4.71 for the $a$ coefficient and between 0.023-3.94 for the $b$ coefficient (Table 5). This metric of how the values of $a$ and those of $b$ vary under repeated sampling reflects a very high quality of the fitted "length-length" models for $S$. mantis. The estimated coefficient of determination $R^{2}$ for all linear models ranged from 0.684-0.82, showing a high degree of linear independence between "total", "cephalothorax" and "telson length" (Table 5). The linear growth model of "telson 
length" versus "cephalothorax length" shows slope coefficients $a$ less than 1 for both sexes and for the overall population, resulting in a majoring allometry. These results sub-imply that cephalothorax grows faster than telson for $S$. mantis specimens. On the other hand, models that relate "total length" to either "cephalothorax" or "telson" reflect growth with minor allometry $(a<1)$, i.e., "total length" grows faster than both "cephalothorax" and "telson" (Table 5). The observed $a$-slope values were compared to the theoretical value of 1 and the difference was statistically significant $(t<1.96)$ for all models developed.

Table 6. Size-weight relationship parameters obtained for the mantis-shrimp S.mantis from the Algiers region (R 4.0.3)

\begin{tabular}{|c|c|c|c|c|c|c|c|c|}
\hline Biometric relation & Sex & $\log \mathbf{a}$ & $\mathbf{b}$ & Std.Error & t value & $\operatorname{Pr}(>|\mathbf{t}|)$ & $\mathbf{R}^{2}$ & $\begin{array}{c}\text { F- } \\
\text { Statistic } \\
\end{array}$ \\
\hline \multirow{3}{*}{$\begin{array}{c}\log \mathrm{Wt}=\log \mathrm{a}+\mathrm{b} \\
\log \mathrm{Lc}\end{array}$} & $\mathrm{F}$ & $\begin{array}{c}0.056(-0.045- \\
0.158)\end{array}$ & 2.78 & $\begin{array}{l}0.05153 \\
0.10547\end{array}$ & $\begin{array}{c}1.092 \\
26.367\end{array}$ & $\begin{array}{c}0.276 \\
<2 \times 10^{-16} * * *\end{array}$ & 0.79 & 695.2 \\
\hline & M & $\begin{array}{c}0.084(-0.034- \\
0.204)\end{array}$ & $\begin{array}{c}2.7 \\
(2.47- \\
2.93)\end{array}$ & $\begin{array}{c}0.06 \\
0.117\end{array}$ & $\begin{array}{c}1.4 \\
23.01\end{array}$ & $\begin{array}{c}0.163 \\
<2 \times 10^{-16} * * *\end{array}$ & 0.77 & 529.6 \\
\hline & Total & $\begin{array}{c}0.075(0.029- \\
0.12)\end{array}$ & $\begin{array}{c}2.77 \\
(2.67- \\
2.86) \\
\end{array}$ & $\begin{array}{l}0.023 \\
0.047 \\
\end{array}$ & $\begin{array}{r}3.20 \\
58.21 \\
\end{array}$ & $\begin{array}{c}0.00145 \\
<2 \times 10^{-16 * * *} \\
\end{array}$ & 0.853 & 3388 \\
\hline \multirow{4}{*}{$\begin{array}{c}\log \mathrm{Wt}=\log \mathrm{a}+\mathrm{b} \\
\log \text { Ltel }\end{array}$} & $\mathrm{F}$ & $\begin{array}{c}0.50(0.42- \\
0.59)\end{array}$ & \begin{tabular}{|c|}
2.52 \\
$(2.29-$ \\
$2.75)$
\end{tabular} & $\begin{array}{l}0.04297 \\
0.11831\end{array}$ & $\begin{array}{l}11.69 \\
21.29\end{array}$ & $\begin{array}{l}<2 \times 10^{-16 * * *} \\
<2 \times 10^{-16} * * *\end{array}$ & 0.71 & 453.1 \\
\hline & \multirow{2}{*}{ M } & \multirow{2}{*}{$\begin{array}{c}0.51(0.42- \\
0.61)\end{array}$} & \multirow{2}{*}{$\begin{array}{c}2.50 \\
(2.26- \\
2.74)\end{array}$} & 0.04699 & 10.95 & $<2 \times 10^{-16} * * *$ & \multirow{2}{*}{0.73} & \multirow[t]{2}{*}{424.3} \\
\hline & & & & 0.12123 & 20.60 & $<2 \times 10^{-16} * * *$ & & \\
\hline & Total & $\begin{array}{c}0.51(0.44- \\
0.57)\end{array}$ & $\begin{array}{l}2.52 \\
(2.35- \\
2.67) \\
\end{array}$ & $\begin{array}{l}0.031 \\
0.082\end{array}$ & $\begin{array}{l}16.41 \\
30.62\end{array}$ & $\begin{array}{l}<2 \times 10^{-16 * * *} \\
<2 \times 10^{-16} * * *\end{array}$ & 0.73 & 937.6 \\
\hline \multirow{4}{*}{$\begin{array}{c}\log \mathrm{Wt}=\log \mathrm{a}+\mathrm{b} \\
\log \mathrm{Lt}\end{array}$} & $\mathrm{F}$ & $\begin{array}{c}-1.83(-2.05,- \\
1.62)\end{array}$ & \begin{tabular}{|c|}
2.89 \\
$(2.7-$ \\
$3.079)$
\end{tabular} & $\begin{array}{l}0.10781 \\
0.09602\end{array}$ & $\begin{array}{c}-17 \\
30.09\end{array}$ & $\begin{array}{l}<2 \times 10^{-16 * * *} \\
<2 \times 10^{-16 * * *}\end{array}$ & 0.83 & 905.6 \\
\hline & \multirow{2}{*}{$\mathrm{M}$} & \multirow{2}{*}{$\begin{array}{c}-2.16(-2.31,- \\
2.003)\end{array}$} & \multirow{2}{*}{$\begin{array}{c}3.19 \\
(3.06- \\
3.33)\end{array}$} & 0.07811 & -27.62 & $<2 \times 10^{-16 * * *}$ & \multirow{2}{*}{0.93} & \multirow[t]{2}{*}{2163} \\
\hline & & & & 0.06865 & 46.51 & $<2 \times 10^{-16} * * *$ & & \\
\hline & Total & $\begin{array}{c}-1.92(-1.99,- \\
1.84)\end{array}$ & $\begin{array}{c}2.97 \\
(2.91- \\
3.05)\end{array}$ & $\begin{array}{l}0.03962 \\
0.03524\end{array}$ & $\begin{array}{l}-48.50 \\
84.45\end{array}$ & $\begin{array}{l}<2 \times 10^{-16} * * * \\
<2 \times 10^{-16 * * *}\end{array}$ & 0.92 & 7132 \\
\hline
\end{tabular}

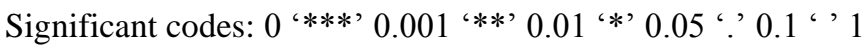

Log transformation of the data for the length-weight relationships linearizes the relationship and erases problems of heteroscedasticity (Table 6). Fisher's $F$ statistic applied on the "log-log" models shows a very high overall significance of the models with varying values between $424.3-7132$ and a $P_{-}$value $<2.2 \times 10^{-16}$, which is significant at $\alpha=0.001$. Student's $t$-test shows high significance of the slope coefficients $b$ at the 99.9\% confidence level $\left(\operatorname{Pr}\left(>|t|<2 \times 10^{-16}\right)\right.$ (Table 6$)$. The values of the intercept $a$ are significant for all models except for the model $\log \mathrm{Wt}=\log \mathrm{a}+\mathrm{b} \log \mathrm{Lc}$. The value of this parameter for the total weight-cephalothoracic height relationship being: $a=1$. The standard error calculated for each of the models indicates confidence interval values 
ranging from 2.26-3.33 and $-2.31-0.57$ for the parameters $b$ and $\log a$ respectively (Table 6).

The estimated $R^{2}$ for each model is very close to 1 (0.71-0.93) indicating a very good fit and a strong linear relationship between the logarithm of weight and the logarithm of length (Table 6 ). The set of tests applied show a very good fit of the length-weight relationships. The slope coefficients $b$ of the models of the length-weight relationship indicates a negative allometry $(b<3)$ and a positive allometry for males of the total weight-total length relationship. This results in a relatively lower weight growth than the "total", "cephalothorax" and "telson length" for both sexes and for the whole population. However, $S$. mantis males show faster growth in "total length" than weight $(b>3)$ (Table 6$)$. The calculated reduced difference $t$-test indicates a significant difference between the observed slope values and the theoretical value of 3 for the length-weight relationships ( $t<1.96, \alpha=0.05)$, except for the two "total length-total weight" relationships for females and combined sex $(t=1.15,0.83<1.96)$. This result suggests that "total weight" growth is proportional to the cube of "total length" growth for females and for the sex-mixed $S$. mantis population (isometry).

\section{Mortality}

The instantaneous total mortality coefficient $(Z)$ for $S$. mantis was $1.32 /$ year. According to Pauly (1983) (Eq. 3), natural mortality $(M)$ was calculated as $0.95 /$ year using $L_{\infty}=18.99 \mathrm{~cm}$ and $K=0.48 \mathrm{yr}^{-1}$ and a water temperature $\left(T^{\circ}\right)$ of $15.3^{\circ} \mathrm{C}$ (Shaltout and Omstedt, 2014). Fishing mortality $(F)$ was $0.37 /$ year (Fig. 6). Exploitation rate $(E)$ indicates whether a stock is overfished based on the fishing mortality rate $(F)$, while assuming that the optimal value of $E$ is approximately equal to 0.5 (Gulland, 1971). The value of $E$ obtained in the present study (0.28) was lower than the optimal value, which is in line with the catches actually observed in the field (under-exploited stock).

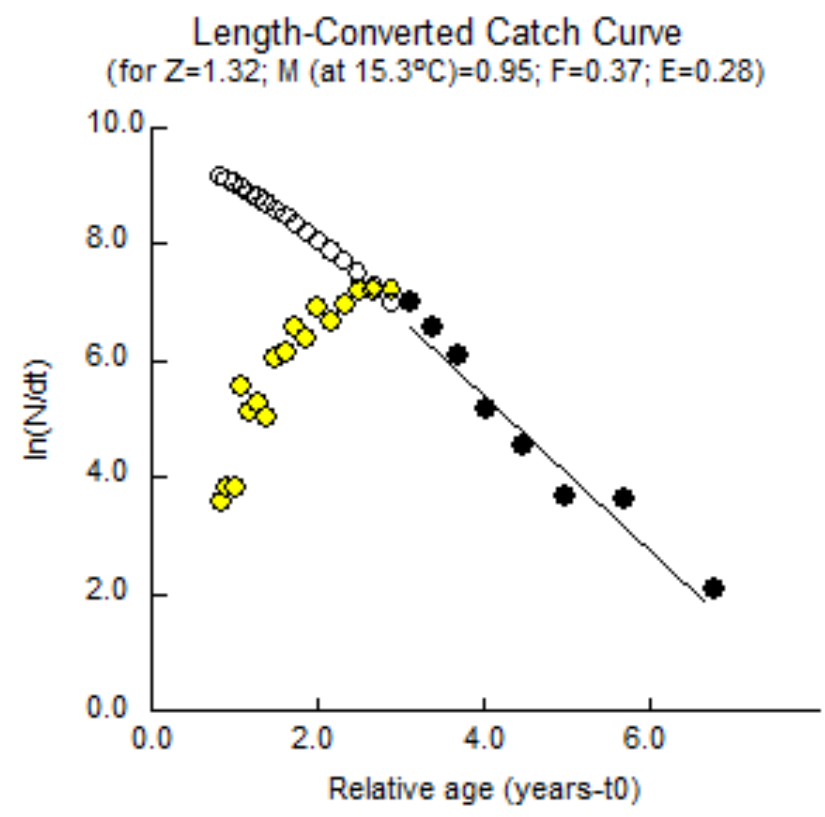

Figure 6. Length-converted catch curve of mantis shrimp from the Mediterranean-Western basin. (Yellow represents points on the ascending part of the catch curve that were not included in the regression analysis to estimate total mortality $Z$. The black dots represent the descenting part used in the estimation of $Z$.) 


\section{Discussion}

The average lengths obtained by the different measurements considered as well as the average total weight are compared with the results of other authors. The average total length $(L t)$ of males $(13.7 \mathrm{~cm})$ is the same as that obtained by Ragonese et al. (2012) and is very close to that observed by Mili et al. (2013) in the Tunis area $(13.92 \mathrm{~cm})$. For females, the average cephalothoracic length $(L c)(3.08 \mathrm{~cm})$ is comparable with those of Mili et al. (2013) in the Gabes area $(3.089 \mathrm{~cm})($ Table 1). The average total weight $(29.18 \mathrm{~g})$ remains between the values of Erdoğan Sağlam et al. (2017): $22.14 \mathrm{~g}$ and Torres et al. (2017): $35.3 \mathrm{~g}$.

For each growth parameter $\left(L_{\infty}, K\right.$, and $\left.t_{0}\right)$ obtained, the calculation was performed using "total length" and "cephalothoracic length". The asymptotic "total length" of females $(18.25 \mathrm{~cm})$ is lower than those of other Mediterranean authors, whereas for males this parameter is very close to that found by Erdoğan Sağlam et al. (2017). The asymptotic "cephalothoracic" length of females $(39.4 \mathrm{~cm})$ is identical to that obtained by Abelló and Martín (1993) (Table 7). For all sexes combined, the present results of growth parameters are very similar than those noted by Erdoğan Sağlam et al. (2017) and Ragonese et al. (2012) (Table 7). The coefficients of catabolism $K$ estimated from "total" and "cephalothoracic lengths" are very similar, with a slight difference in favor of females. These estimated coefficients are consistent with the more or less low longevity character of the squilla $S$. mantis (Maynou et al., 2004).

Table 7. Growth parameters obtained by different authors in the Mediterranean Sea

\begin{tabular}{|c|c|c|c|c|c|c|c|c|}
\hline Authors & Region & $\begin{array}{c}\text { Length } \\
\text { measurment }\end{array}$ & Sexe & $\mathbf{N}$ & $\boldsymbol{L}_{\infty}(\mathbf{m m})$ & $K\left(\mathbf{y}^{-1}\right)$ & $t_{0}(\mathbf{y})$ & $\emptyset^{\prime}$ \\
\hline \multirow{3}{*}{$\begin{array}{c}\text { Froglia } \\
(1996)\end{array}$} & \multirow{3}{*}{$\begin{array}{c}\text { Central Adriatic } \\
\text { Sea }\end{array}$} & \multirow{3}{*}{$\mathrm{Lc}$} & $F$ & & 41.88 & 0.448 & -0.038 & 2.90 \\
\hline & & & $M$ & & 41.18 & 0.532 & -0.059 & 2.96 \\
\hline & & & $F+M$ & & 41.53 & 0.49 & -0.010 & 2.93 \\
\hline Righini \& & \multirow{2}{*}{ Ligurian Sea } & \multirow{2}{*}{$\mathrm{Lt}$} & $F$ & & 220 & 1.45 & & 4.85 \\
\hline Baino (1996) & & & $M$ & & 225 & 1.3 & & 4.82 \\
\hline $\begin{array}{c}\text { Ragonese et } \\
\text { al (2012) }\end{array}$ & $\begin{array}{c}\text { Southern coasts of } \\
\text { Sicily }\end{array}$ & $\mathrm{Lt}$ & $F+M$ & 484 & 190 & 0.41 & -0.52 & 4.17 \\
\hline \multirow{6}{*}{$\begin{array}{l}\text { Mili et al. } \\
2013\end{array}$} & \multirow{4}{*}{$\begin{array}{c}\text { Gulf of Tunis } \\
\text { Gulf of } \\
\text { Hammamet }\end{array}$} & \multirow{6}{*}{$\mathrm{Lt}$} & $F$ & 1564 & 179.1 & 1.44 & -0.57 & 4.66 \\
\hline & & & $M$ & 1726 & 188.3 & 1.400 & -0.39 & 4.70 \\
\hline & & & $F$ & 1404 & 187.1 & 1.430 & -0.24 & 4.70 \\
\hline & & & $M$ & 1620 & 198.2 & 1.330 & -0.26 & 4.72 \\
\hline & \multirow{2}{*}{ Gulf of Gabes } & & $F$ & 7799 & 188.4 & 1.560 & -0.31 & 4.74 \\
\hline & & & $M$ & 8770 & 204.6 & 1.330 & -0.3 & 4.75 \\
\hline \multirow{6}{*}{$\begin{array}{c}\text { Erdogan } \\
\text { Saglam et al. } \\
(2017)\end{array}$} & \multirow{6}{*}{$\begin{array}{c}\text { Izmir Bay } \\
\text { (Aegean Sea) }\end{array}$} & \multirow{4}{*}{$\mathrm{Lt}$} & $F$ & 549 & 192.8 & 0.510 & -0.36 & 4.28 \\
\hline & & & $M$ & 387 & 183.43 & 0.420 & -0.45 & 4.15 \\
\hline & & & $F+M$ & 936 & 196.9 & 0.500 & -0.37 & 4.29 \\
\hline & & & $F$ & 549 & 46.3 & & & \\
\hline & & \multirow[t]{2}{*}{$\mathrm{Lc}$} & $M$ & 387 & 45.7 & & & \\
\hline & & & $F+M$ & 936 & 47.4 & & & \\
\hline \multirow{6}{*}{$\begin{array}{l}\text { Present } \\
\text { study }\end{array}$} & \multirow{6}{*}{$\begin{array}{l}\text { Algiers region } \\
\text { (SW Medit.) }\end{array}$} & \multirow{4}{*}{$\mathrm{Lt}$} & $F$ & 490 & 182.5 & 0.69 & -0.56 & 4.36 \\
\hline & & & $M$ & 422 & 185.6 & 0.67 & -0.57 & 4.36 \\
\hline & & & $F+M$ & 1064 & 189.9 & 0.48 & -0.66 & 4.24 \\
\hline & & & $F$ & 490 & 39.40 & 0.71 & -0.51 & 3.04 \\
\hline & & \multirow[t]{2}{*}{$\mathrm{Lc}$} & $M$ & 422 & 42.50 & 0.64 & -0.53 & 3.06 \\
\hline & & & $F+M$ & 1064 & 48.06 & 0.34 & -0.69 & 2.90 \\
\hline
\end{tabular}


The determination of the age-length key, established from the method of Bhattacharya (1967) and the Von Bertalanffy curve (Eq. 1), has given satisfactory results. Indeed, between three and four age classes are observed in most Mediterranean authors (Figs. 4,5); the studies carried out in the Bay of Cadiz (northeastern Atlantic Ocean), based on the length of the carapace, have determined two age groups in females and males (Vila et al., 2013); this same result was also observed by Mili et al. (2013) on the Tunisian coast. On the southern coasts of Sicily, three age groups are observed (1-3) (Ragonese et al., 2012). Erdoğan Sağlam et al. (2017) note four age groups in Izmir Bay (Aegean Sea), a result similar to this work (Figs. 4,5). The differences found with previous authors may be due to the methods used for size structure decomposition or simply the vagaries of sampling. The difference between the study areas where the samples were taken could be the first source of variability in the results.

The length versus age correspondence presented by Bhattacharya's method of total length in males and females shows very similar lengths with Ragonese et al. (2012) and the same size of $15.7 \mathrm{~cm}$ obtained at age 3 in females with Erdoğan Sağlam et al. (2017) (Table 4).

The growth parameters given by this study are very comparable with other Mediterranean research (Table 7). Indeed, Mili et al. (2013) presented very similar values in the Gulf of Tunis, Hammamet and Gabes. This emphasizes the current results given the proximity of the two study regions. For all sexes, the asymptotic total length is identical to that found by Ragonese et al. (2012). As for the results based on "cephalothorax length", the asymptotic length of males $\left(L c_{\infty}\right)$ is close to that obtained by Froglia (1996) in the central Adriatic Sea. The growth rate $K$ is between 0.41 /year and 1.56/year for $S$. mantis, the results obtained in this study are within this range except for both sexes combined considering "cephalothorax length" (0.34/year) (Table 7).

This difference found with other authors who determined the growth parameters of $S$. mantis can likely be attributed to the environmental conditions (temperature, salinity, nutrients) or to the fishing pressure exerted on the stock of this species which differs according to the region. According to the growth performance estimated in this study (Table 7), the values of $\emptyset^{\prime}$ are greater in the Ligurian Sea (Righini and Baino, 1996) and in the Gulfs of Tunis, Hammamet, and Gabes (Mili et al., 2013) but are highly similar compared to those in the central Adriatic Sea and Izmir Bay (Froglia, 1996; Erdoğan Sağlam et al., 2017) (Table 7).

Concerning the biometric relationships, the "length-length" relationships are strong $\left(R^{2}=0.68-0.82\right)$, with a slope a for both sexes between 0.67 and 4.88: for females $(0.67<a<4.88)$ and males $(0.67<a<4.33)$ indicating a growth with minoring allometry $(a<1)$ for telson size versus cephalothorax. A growth with majoring allometry $(a>1)$ was recorded for the "total-length-cephalothorax" and "total-length-telson" relationships for both sexes, reflecting a higher total growth than both sizes; cephalothorax and that of telson (Table 5). As for the "total weight-cephalothorax length", "total weight-telson length" and "total weight-total length" relationships, the coefficient of determination $R^{2}$ is very high (0.71-0.93), reflecting a strong body response of weight to length changes in the S. mantis population (Table 6). Erdoğan Sağlam et al. (2017) found isometry in the "total length-weight" relationship for males and females, with slope values equal to 2.95 and 3.02, respectively, reflecting isometry (Table 8).

The "length-length" relationship ( $L t-L c)$ gives values close to those of Mili et al. (2008) in the Gabes region (Table 8). This author is the only one who considered the 
length of the telson and their results are very comparable to this study (Tables 5,8). Indeed, the calculated Ltel-Lc relationship gives an " $a$ " in males and females $(0.67$ and 0.66 , respectively) close to the one obtained by Mili et al (2008) in Gabes (0.73 and 0.70). The "length-weight" relationship $(W t-L t)$ of our results, showing an isometry between length growth and weight growth, are also very comparable to those of Ragonese et al. (2012) and Erdoğan Sağlam et al. (2017) for females, males and for both sexes combined. As for the Wt-Lc relationship, the results are supported by those reported by Righini and Baino (1996), Abelló (1989), Mili et al. (2008) (Hammamet), Vila et al. (2013) and Erdoğan Sağlam et al. (2017).

Table 8. Length-weight and length-length relationship parameters obtained by different authors in the Mediterranean

\begin{tabular}{|c|c|c|c|c|c|c|c|c|}
\hline \multirow{2}{*}{ Authors } & \multirow{2}{*}{ Region } & \multirow{2}{*}{ Relation } & \multicolumn{2}{|c|}{ Male } & \multicolumn{2}{|c|}{ Female } & \multicolumn{2}{|c|}{ Combined } \\
\hline & & & a & b & a & b & $\mathbf{a}$ & b \\
\hline $\begin{array}{c}\text { Giovanardi and } \\
\text { Piccinetti Manfrin } \\
(1984)\end{array}$ & Adriatic Sea & Lc-Wt & 0.0116 & 3.0431 & 0.0138 & 2.9168 & & \\
\hline \multirow{2}{*}{$\begin{array}{l}\text { Abello and Sarda } \\
\text { (1989) }\end{array}$} & \multirow{2}{*}{$\begin{array}{c}\text { Ebro delta } \\
\text { (NW } \\
\text { Mediterranean } \\
\end{array}$} & $\mathrm{Lc}-\mathrm{Wt}$ & 0.0026 & 2.8305 & 0.0020 & 2.9026 & & \\
\hline & & $\mathrm{Lc}-\mathrm{Lt}$ & 0.7637 & 0.8937 & 0.6164 & 0.9523 & & \\
\hline Froglia (1996) & Adriatic Sea & Lc-Wt & 0.0014 & 3.0425 & 0.0014 & 3.0419 & & \\
\hline $\begin{array}{c}\text { Righini and Baino } \\
(1996)\end{array}$ & Ligurian Sea & $\mathrm{Lc}-\mathrm{Wt}$ & 0.0356 & 2.6100 & 0.0526 & 2.4100 & & \\
\hline \multirow{9}{*}{ Mili et al.(2008) } & \multirow{3}{*}{$\begin{array}{l}\text { Tunisian water } \\
\text { (Tunis) }\end{array}$} & Ltel-Lc & 0.786 & 1.0135 & 0.8592 & 0.99 & 0.821 & 1.0021 \\
\hline & & $\mathrm{Lc}-\mathrm{Lt}$ & 5.4649 & 0.9374 & 4.8955 & 0.9712 & 5.2613 & 0.9526 \\
\hline & & $\mathrm{Lc}-\mathrm{Wt}$ & 0.0008 & 3.026 & 0.0006 & 3.11 & 0.0007 & 3.0673 \\
\hline & \multirow{3}{*}{$\begin{array}{l}\text { Tunisian water } \\
\text { (Hammamet) }\end{array}$} & Ltel-Lc & 0.9387 & 0.9644 & 0.9168 & 0.972 & 0.9269 & 0.9684 \\
\hline & & Lc-Lt & 5.5116 & 0.9389 & 5.1155 & 0.6909 & 5.299 & 0.9505 \\
\hline & & $\mathrm{Lc}-\mathrm{Wt}$ & 0.0013 & 2.8864 & 0.0011 & 2.9165 & 0.0012 & 2.9019 \\
\hline & \multirow{3}{*}{$\begin{array}{c}\text { Tunisian water } \\
\text { (Gabes) }\end{array}$} & Ltel-Lc & 0.7302 & 1.0414 & 0.7087 & 1.0624 & 0.7211 & 1.0461 \\
\hline & & $\mathrm{Lc}-\mathrm{Lt}$ & 4.9131 & 0.9776 & 4.494 & 1.0553 & 4.7074 & 0.9909 \\
\hline & & Lc-Wt & 0.0006 & 3.1279 & 0.0006 & 3.1555 & 0.0006 & 3.1431 \\
\hline $\begin{array}{c}\text { Ragonese et al. } \\
\text { (2012) }\end{array}$ & South of Sicily & Lt-Wt & -11.561 & 3.031 & -11.534 & 3.027 & & \\
\hline \multirow{2}{*}{ Vila et al. (2013) } & \multirow{2}{*}{$\begin{array}{l}\text { Gulf of Cadiz } \\
\text { (E-C Atlantic) }\end{array}$} & Lc-Lt & 6.8589 & 0.8879 & 7.2757 & 0.8766 & 7.3949 & 0.8693 \\
\hline & & Lc-Wt & 0.00677 & 2.5465 & 0.004347 & 2.6725 & 0.005118 & 2.6263 \\
\hline \multirow{3}{*}{$\begin{array}{l}\text { Erdogan Saglam } \\
\quad \text { et al. (2017) }\end{array}$} & \multirow{3}{*}{ Izmir Bay } & Lc-Lt & 0.2317 & 0.1087 & 0.2410 & 0.0117 & 0.2373 & 0.0378 \\
\hline & & Lc-Wt & 0.7733 & 2.92 & 0.8670 & 2.87 & 0.8046 & 2.91 \\
\hline & & Lt-Wt & 0.0111 & 2.95 & 0.0098 & 3.02 & 0.0098 & 3.02 \\
\hline $\begin{array}{c}\text { Torres et al. } \\
(2017)\end{array}$ & Gulf of Cadiz & Lc-Wt & & & & & 1.709 & 2.842 \\
\hline $\begin{array}{l}\text { Kampouris et al. } \\
\text { (2018) }\end{array}$ & $\begin{array}{c}\text { Gulf of } \\
\text { Thermaikos } \\
\text { Aegean Sae }\end{array}$ & Lc-Wt & 2.670 & 2.737 & 2.941 & 3.189 & 2.881 & 3.087 \\
\hline \multirow{6}{*}{ Present study } & \multirow{6}{*}{$\begin{array}{l}\text { Algiers region } \\
\text { (SW Medit.) }\end{array}$} & Lc-Wt & 1.0876 & 2.7 & 1.0575 & 2.78 & 1.0778 & 2.77 \\
\hline & & Ltel-Wt & 1.6652 & 2.50 & 1.6487 & 2.52 & 1.6652 & 2.52 \\
\hline & & Lt-Wt & 0.1153 & 3.19 & 0.1604 & 2.89 & 0.1466 & 2.97 \\
\hline & & Ltel-Lc & 0.67 & 0.23 & 0.668 & 0.24 & 0.669 & 0.24 \\
\hline & & Ltel- Lt & 3.33 & 3.22 & 4.477 & 2.973 & 4.36 & 3.19 \\
\hline & & Lc-Lt & 3.46 & 2.40 & 3.795 & 1.60 & 3.78 & 1.70 \\
\hline
\end{tabular}


The calculation of exploitation indices provided insight into the status of the stock. Fishing mortality $F$ is 0.95 year, a value very close to that recorded in southern Sicily by Ragonese et al. (2012), but still lower than that found by Erdoğan Sağlam et al. (2017) in Izmir Bay in 2017 (1.16/year). The latter Mediterranean region exploits mantis shrimp weakly with an exploitation rate of 0.39. In the central Algerian region, this exploitation is even lower; $E$ is equal to 0.28 because the fishery does not target this species (Fig. 6).

\section{Conclusion}

This study is the first of its kind to give results on the growth parameters and mortality of $S$. mantis from Algeria. It was based on length-frequency data which can, provide valuable information on the life history of the mantis shrimp in this country.

Overall, the study contributed to the knowledge of the population dynamics of $S$. mantis exploited in the central region of Algeria and provided basic parameters essential for the management of the stock of this species in this area. We showed that the spottail mantis shrimp has a rapid growth in this area and a low longevity. The study of biometric relationships revealed the following findings: a) growth in "total weight" is proportional to the cube of growth in "total length" for females and for the mixed-sex population of $S$. mantis (isometry) and b) growth with a major allometry for males. For growth in length, cephalothorax grows faster than telson for all S. mantis specimens and "total length" grows faster than "cephalothorax" and "telson".

This study carried out from the catches of the commercial fishery in the central region of Algeria shows an under-exploitation of the $S$. mantis stock. Nevertheless, the fishing statistics of this species show an evolution of the catches in 2016. This limited fishing pressure may be considered as an important issue to protect the $S$. mantis population in this region. In this study, it is noted that the fishery is carried out by trawls with a large horizontal opening, but it is discarded at sea. In our country, the discarding of this species, which is beginning to attract consumers, represents a loss for the national economy and the regional fishery.

In other countries such as Italy, Spain, France and Slovenia, this species is economically valued. As a result of this study, the population parameters of $S$. mantis are similar to those of the European countries that fish this species economically. It could be exported to European countries or fished as a target species instead of being discarded in Algeria. The lack of knowledge concerning the biology of S. mantis is evident and further research is needed. The present study is the first one carried out in Bou-Ismail Bay (central region of Algeria). Future studies should focus more on this species in order to enhance its value.

Acknowledgements. The authors express their thanks to Michael Sievers of Griffith University in Australia for editing the scientific English of this manuscript. Thanks are also expressed to the reviewers for their advice and suggestions.

\section{REFERENCES}

[1] Abelló, P., Sardá, F. (1989): Some observations on the biology and fishery of Squilla mantis L. in the Catalan area (NW Mediterranean Sea). - Biology of Stomatopods: Selected Symposia and Monographs UZI, 3.- Mucchi: 229-239. 
[2] Abelló, P., Martín, P. (1993): Fishery dynamics of the mantis shrimp Squilla mantis (Crustacea: Stomatopoda) population off the Ebro delta (northwestern Mediterranean). Fisheries Research 16: 131-145.

[3] Beverton, R. J., Holt, S. J. (2012): On the dynamics of exploited fish populations. Springer Science and Business Media.

[4] Bhattacharya, C. G. (1967): A simple method of resolution of a distribution into Gaussian components. - Biometrics 23(1): 115-135.

[5] Campilo, A. (1982): Algerie 82 (THALASSA) cruise. - Thalassa R/V.

[6] Derbal, F., Kara, M. (2006): Données préliminaires sur la biologie de la crevette Plesionika edwardsii (Crustacea, Pandalidae) du golfe d'Annaba (Algérie, est). - Bull. INSTM, NS (9) - Actes des 7èmes Journées de L'ATSMer, Zarzis, Tunisie.

[7] Derbal, F., Soltani, N. (2008): Cycle cuticulaire et variations de la protéinémie et de la lipémie chez la crevette royale Penaeus kerathurus (Forskal, 1775) des côtes Est algériennes. Sciences and Technologie. - Biotechnologies, pp. 80-86.

[8] Erdoğan Sağlam, N., Demir Sağlam, Y., Sağlam, C. (2017): A study on some population parameters of mantis shrimp (Squilla mantis L., 1758) in Izmir Bay (Aegean Sea). Journal of the Marine Biological Association of the United Kingdom 98: 721-726.

[9] Froglia, C. (1996): Growth and behaviour of Squilla mantis (mantis shrimp) in the Adriatic Sea. - EU Study DG XIV. MED/93/016, Final Report.

[10] Gayanilo, J., Sparre, P., Pauly, D. (2002): FAO-ICLARM fish stock assessment tools (FiSAT II): user's manual. - Rome: International Center for Living Aquatic Resources Management and Food and Agriculture Organization of the United Nations.

[11] Giovanardi, C., Piccinetti-Manfrin, G. (1984): Summary of biological parameters of Squilla mantis L. in the Adriatic Sea. - FAO Fish. Rep 290: 131-134.

[12] Gulland, J. (1971): The fish resources of the ocean. - West Byfleet, Surrey. Fishing News (Books), Ltd., for FAO, 255.

[13] Holthuis, L. (1987): Stomatopodes. Fiches FAO d'identification des espèces pour les besoins de la pêche. - Méditerranée et Mer Noire 1: 181-187.

[14] Kampouris, T. E., Kouroupakis, E., Lazaridou, M., Batjakas, I. E. (2018): Length-weight relationships of Squilla mantis (Linnaeus, 1758) (Crustacea, Stomatopoda, Squillidae) from Thermaikos Gulf, North-West Aegean Sea, Greece. - International Journal of Fisheries and Aquatic Studies 6: 241-246.

[15] Kennouche, H. (2009): Biologie, ecologie et exploitation de la crevette rouge Aristeus antennatus dans la région d'Alger. - Thesis USTHB, 87p.

[16] King, M. (2013): Fisheries biology, assessment and management. - John Wiley \& Sons.

[17] Manning, R. B. (1977): A monograph of the West African stomatopod Crustacea. Scandinavian Science Press.

[18] Masson, J. (1970): Estimation des paramètres d'un mélange de distributions gaussiennes. - Station.

[19] Maynou, F., Abelló, P., Sartor, P. (2004): A review of the fisheries biology of the mantis shrimp, Squilla mantis (L., 1758) (Stomatopoda, Squillidae) in the Mediterranean. Crustaceana: 1081-1099.

[20] MFFP. (2021): Regional report on fishing statistics in the central region of Algeria. Ministry of Fisheries and Fisheries Production, Algiers.

[21] Mili, S., Jarboui, O., Missaoui, H. (2008): Caractères biométriques de la squille Squilla mantis dans les eaux tunisiennes. - Bulletin de l'institut national des sciences et technologies de la mer Salommbo 35: 1-14.

[22] Mili, S., Bouriga, N., Missaoui, H., Jarboui, O. (2011): Morphometric, reproductive parameters and seasonal variations in fatty acid composition of the mantis shrimp Squilla mantis (Crustacea: Stomatopoda) in the Gulf of Gabes (Tunisia). - Journal of Life Sciences 5: 1058-1071.

[23] Mili, S. (2013): La squille Squilla mantis des eaux tunisiennes: eco-biologie, pêche et opportunités de valorisation. - Thesis, Institut national agronomique de Tunis, 196p. 
[24] Mili, S., Ennouri, R., Jarboui, O., Missawi, H. (2013): Premiere approche de la croissance de la squille Squilla mantis (L., 1758) dans les eaux tunisienneas. - Bulletin de l'institut national des sciences et technologies de la mer Salommbo 40: 27-42.

[25] Mili, S., Ennouri, R., Jarboui, O., Missaoui, H. (2014): Étude de la biologie de reproduction chez la squille ocellée Squilla mantis pêchée dans trois golfes tunisiens: Tunis, Hammamet et Gabès. - Bulletin de Société zoologique de France 139: 215-232.

[26] Moreau, J., Bambino, C., Pauly, D. (1986): A comparison of four indices of overal fish growth performance, based on 100 tilapia population (Cichlidae): 201-206. - In: Maclean, J. L., Dizon, L. B., Hosillo, L. V. (eds.) The first Asian fisheries forum. Asian Fisheries Society, Manilla, Philippines.

[27] Mouffok, S., Kherraz, A., Bouras, D., Bennoui, A., Boutiba, Z. (2005): Premières observations biologiques de la crevette profonde Aristeus antennatus (Decapoda: Aristeidae) exploitée le long du littoral occidental algérien (Méditérannée du sud-ouest). - Editorial Advisory Board E: 817.

[28] Mouffok, S., Massuti, E., Boutiba, Z., Guijarro, B., Ordines, F., Fliti, K. (2008): Ecology and fishery of the deep-water shrimp, Aristeus antennatus (Risso, 1816) off Algeria (South-western Mediterranean). - Crustaceana 81(10): 1177-1199.

[29] Nouar, A., Kennouche, H. (2013): Régime alimentaire de la crevette rouge Aristeus antennatus (Risso, 1816) (Decapoda, Penaeoidea) dans la région algéroise (Algérie centre). - Crustaceana 86: 553-563.

[30] Pauly, D. (1980): On the interrelationships between natural mortality, growth parameters, and mean environmental temperature in 175 fish stocks. - ICES Journal of Marine Science 39: 175-192.

[31] Pauly, D. (1983): Some simple methods for the assessment of tropical fish stocks. - FAO, Fishery Technics Reports 234, 52p.

[32] Powell, D. (1979): Estimation of mortality and growth parameters from the length frequency of a catch [model]. - Rapports et Proces-Verbaux des Reunions (Denmark).

[33] R Core Team (2020): R: A language and environment for statistical computing. - R Foundation for Statistical Computing, Vienna, Austria. URL http://www.R-project.org/.

[34] Ragonese, S., Morara, U., Canali, E., Pagliarino, E., Bianchini, M. L. (2012): Abundance and biological traits of the spottail mantis shrimp, Squilla mantis (L., 1758) (Crustacea: Stomatopoda), off the southern coast of Sicily. - Cahiers de Biologie Marine 53: 485.

[35] Ricker, W. E. (1975): Computation and interpretation of biological statistics of fish populations. - Bulletin of Fisheries Research 191: 1-382.

[36] Righini, P., Baino, R. (1996): Parametri popolazionistici della pannocchia (Squilla mantis, Crustacea, Stomatopoda). - Biologia Marina Mediterranea 3: 565-566.

[37] Schram, F. R., Muller, H. G. (2004): Catalog and bibliography of the fossil and Recent Stomatopoda. - Backhuys, 264p.

[38] Shaltout, M., Omstedt, A. (2014): Recent sea surface temperature trends and future scenarios for the Mediterranean Sea. - Oceanologia 56: 411-443.

[39] Sparre, P., Venema, C. S. (1992): Introduction to tropical fish stock assessment. - Part. 1 Manual, FAO.

[40] Tomlinson, P. K., Abramson, N. J. (1961): Fitting a von Bertalanffy growth curve by least squares. - Fisheries Bulletin 116: 3-69.

[41] Torres, M. A., Vila, Y., Silva, L., Acosta, J. J., Ramos, F., Palomares, M. L. D., Sobrino, I. (2017): Length-weight relationships for 22 crustaceans and cephalopods from the Gulf of Cadiz (SW Spain). - Aquatic Living Resources 30: 12.

[42] Vasconcelos, P., Carvalho, A. N., Pilo, D., Gaspar, M. B., Cristo, M. (2017): First record of the spottail mantis shrimp, Squilla mantis (Stomatopoda, Squillidae), in the Ria Formosa lagoon (Algarve coast, southern Portugal). - Crustaceana 90: 1665-1671.

[43] Veneroni, B., Fernandes, P. G. (2021): Fishers' knowledge detects ecological decay in the Mediterranean Sea. - Ambio 50: 1159-1171. 
[44] Vila, Y., Sobrino, I., Jiménez, M. P. (2013): Fishery and life history of spot-tail mantis shrimp, Squilla mantis (Crustacea: Stomatopoda), in the Gulf of Cadiz (eastern central Atlantic). - Scientia Marina 77: 137-148.

[45] Wetherall, J. (1986): A new method for estimating growth and mortality parameters from length frequency data. - Fishbyte 4: 12-14. 